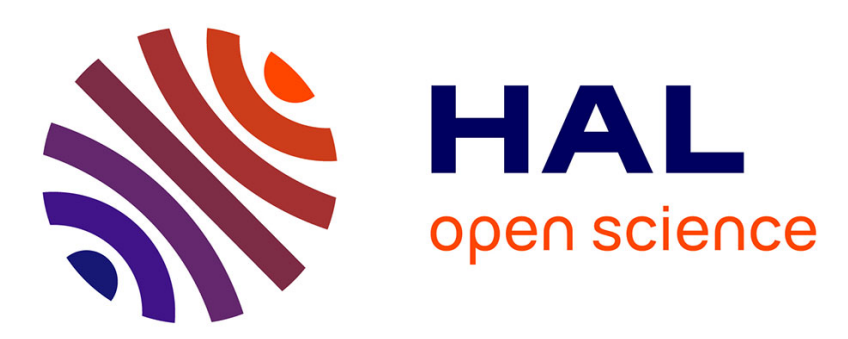

\title{
A giant limulid trackway (Kouphichnium lithographicum) from the lithographic limestones of Cerin (Late Kimmeridgian, France) : ethological and environmental implications \\ Christian Gaillard
}

\section{To cite this version:}

Christian Gaillard. A giant limulid trackway (Kouphichnium lithographicum) from the lithographic limestones of Cerin (Late Kimmeridgian, France) : ethological and environmental implications. Swiss Journal of Geosciences, 2011, 104 (1), pp.S57-S72. 10.1007/s00015-010-0032-2 · hal-00659624

\section{HAL Id: hal-00659624 \\ https://hal.science/hal-00659624}

Submitted on 27 Nov 2021

HAL is a multi-disciplinary open access archive for the deposit and dissemination of scientific research documents, whether they are published or not. The documents may come from teaching and research institutions in France or abroad, or from public or private research centers.
L'archive ouverte pluridisciplinaire HAL, est destinée au dépôt et à la diffusion de documents scientifiques de niveau recherche, publiés ou non, émanant des établissements d'enseignement et de recherche français ou étrangers, des laboratoires publics ou privés. 


\title{
A giant limulid trackway (Kouphichnium lithographicum) from the lithographic limestones of Cerin (Late Kimmeridgian, France): ethological and environmental implications
}

\author{
Christian Gaillard
}

Received: 20 August 2009/Accepted: 18 August 2010/Published online: 26 October 2010

(C) Swiss Geological Society 2010

\begin{abstract}
A well-preserved large limulid trackway related to Kouphichnium lithographicum is described from the Upper Kimmeridgian Lithographic Limestones of Cerin (Ain, France). It is three meters long and exhibits ten successive sets of imprints characterized by a pair of wellpreserved tetradactyl external imprints of legs VI (named pushers) and a variable number (mostly three pairs) of straight thin intermediate imprints (legs III-V). The trackway is unusually wide and was probably made by a very large adult approximately $38 \mathrm{~cm}$ wide and $80 \mathrm{~cm}$ long when related to the proportions of the modern Limulus polyphemus. The straightness of the trackway, the great repeat distance (stride), the length of series of leg imprints, their slight angle to the mid-line, the well-marked pusher (= leg VI) imprints and the absence of groove made by the telson all indicate fast progression of a vigorous animal on the sea-floor. This walking trackway can be easily differentiated from other limulid crawling, ploughing, and dying trackways usually found in lithographic limestones or other deposits of the geological record. Main characteristics of these different limulid trackways are evidenced. The occurrence of a living adult in the Cerin restricted lagoon is probably related to a brief period of connection with the open sea. This occurrence indicates either a passive introduction of the animal into the lagoon or a spawning behaviour.
\end{abstract}

Editorial handling: Christian A. Meyer and Daniel Marty.

C. Gaillard $(\bowtie)$

Université de Lyon, CNRS, UMR 5125 PaléoEnvironnements et

PaléobioSphère, 69622 Lyon, France

e-mail: christian.gaillard@univ-lyon1.fr
Keywords Kouphichnium - Limulid trackway · Late Jurassic - Cerin lithographic limestones · Ethology . Palaeoenvironment

\section{Introduction}

Limulids (class: Merostomata; subclass: Xiphosura), commonly called "horseshoe crabs", are very distinctive and interesting arthropods. Merostomata are known from the Early Cambrian, and fossil limulids which are very similar to their modern relatives (suborder Limulina, Richter and Richter 1929) are known from the Devonian, perhaps Ordovician (Rudkin et al. 2008), and they show a maximum diversity during Triassic time (Moore et al. 2007). For these reasons, horseshoe crabs are classically considered as "living fossils" (Barthel 1974; Fischer 1984) and benefit from the special attention of palaeontologists. Living animals are well known and correspond to a North American species (Limulus polyphemus) and three Indopacific species (Carcinoscorpius rotundicaudata, Tachypleus gigas and Tachypleus tridentatus). A great amount of biological and ecological data is available, mainly for Limulus polyphemus (Eldredge 1970; Vosatka 1970; Rudloe 1981; Shuster and 1982; Botton 1984; Botton and Ropes 1987; Sekiguri 1988; Brockmann 1990; Shuster et al. 2003; Martin and Rindsberg 2007). Because of the special status of these animals, new data from the fossil record are of considerable paleontological and paleoecological interest.

Limulid trackways yield very informative data but they were first misinterpreted and attributed to diverse vertebrates such as dinosaurs, pterosaurs or primitive birds (Walther 1904; Jaekel 1929; Abel 1935; Caster 1938, 1939; Malz 1964). The name of the ichnospecies Ornichnites 
caudatus proposed by Jaekel (1929), which is a clear synonym of Kouphichnium lithographicum, illustrates this misinterpretation. Today, these traces are well known, are mainly related to the ichnogenus Kouphichnium and lead to interesting behavioural conclusions. They are mainly known from Upper Palaeozoic (Willard 1935; Hardy 1970; Miller 1982; Chisholm 1983; Eagar et al. 1985; Conti et al. 199I), Triassic (Caster 1939, 1944; Linck 1943; Nielsen 1949; Wang 1993), and Jurassic (Oppel 1862; Caster 1940; Kolb 1963; Barthel 1974; Groiss 1975; Romano and Whyte 1987; Barthel et al. 1990; Schweigert 1998; Viohl 1998; Schweigert and Dietl 2002; Harris and Lacovara 2004) rocks. However, an impressive Oligocene trackway was also reported from Japan (Oishi et al. 1993; Lockley and Matsukawa 2009). Among the best traces are the trackways from the Upper Jurassic Lagerstätte of Solnhofen (Bavaria, Germany). Some of them are very famous because they include the dying animal at their end and are thus classified as mortichnia (Barthel 1978; Seilacher 2007). Traces illustrating the normal locomotion of living animals provide more information about the behaviour of limulids (Caster 1944; Goldring and Seilacher 1971). Such traces are often reported but generally without precise description. The Upper Jurassic lagerstätte of Cerin (lithographic limestones, Late Kimmeridgian) has yielded a remarkable limulid trackway whose detailed description is justified because of both an excellent preservation and a very large size. The trackway is exceptionally long and documents a relatively long period of locomotion. It is also very wide and implies a giant trackmaker.

\section{Materials and methods}

The Cerin Lagerstätte is situated $80 \mathrm{~km}$ East of Lyon in the Southern Jura Mountains (Fig. 1). A scientific excavation was organized in an abandoned quarry (Bernier et al. 1991a) where the lithographic limestone had been quarried during the nineteenth century (Bourseau et al. 1984). A bed-by-bed study including the systematic investigation of upper bedding surfaces measuring $70-150 \mathrm{~m}^{2}$ was carried out. Many new observations have been published concerning trace fossils (Bernier et al. 1982, 1984; Gaillard et al. 1994b, 2003), algae (Bernier et al. 1991a, b), jellyfish (Gaillard et al. 2006), ammonites (Enay et al. 1994), asteroids (Breton et al. 1994), ophiuroids (Bourseau et al. 1991), echinoids (Bourseau et al. 1994), fish (Wenz et al. 1994), and pterosaurs (Buffetaut et al. 1990). Two specimens of limulids were also discovered (Gall et al. 1996) but limulid trackways had never been recorded before this study.

The Cerin Lithographic Limestone Formation was formed during the Late Kimmeridgian/Early Tithonian

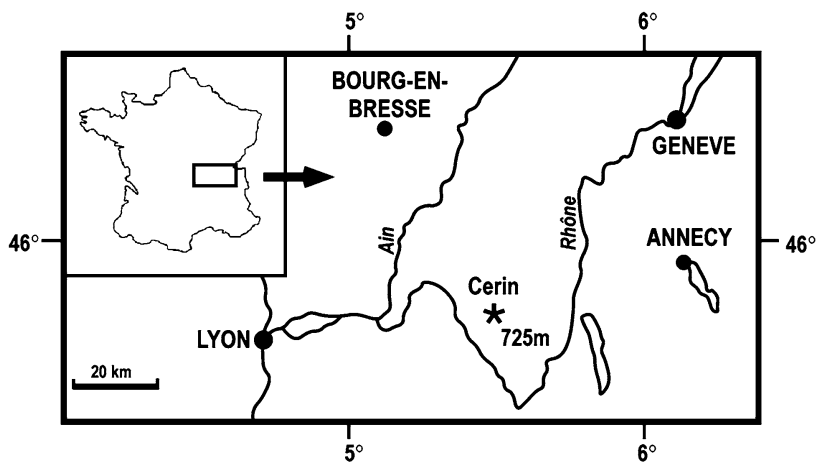

Fig. 1 Location of the Cerin Lagerstätte (Ain, France; $45^{\circ} 46^{\prime} 44^{\prime \prime}$ $\mathrm{N}-5^{\circ} 33^{\prime} 15^{\prime \prime} \mathrm{E}$ )

(Enay et al. 1994). It consists of laminites at the base including rare flints overlain by the Lithographic Limestone sensu stricto where laminites alternate with thicker beds. Schematically, the thickness of micritic beds gradually increases from a few millimetres at the base to $5-25 \mathrm{~cm}$ at the top of the sequence. The rock is a typical lithographic limestone composed of a very pure, fine micrite (Bernier 1994). The grain size is generally $2-4 \mu \mathrm{m}$. Like the Solnhofen Lithographic Limestone, the Cerin Lithographic Limestone may be considered as an obrutionary stagnation deposit (Seilacher et al. 1985). Sedimentary structures and trace fossils indicate frequent emersions (Bernier et al. 1982, 1991c; Gaillard et al. 1994; Gall et al. 1985). The precise palaeoenvironment corresponds to the margin of a shallow tropical lagoon located on an extinct coral reef complex (Bernier 1984; Bernier et al. 1994; Gaillard et al. 1994). This dead coral reef complex belonged to a wide shallow carbonate platform bordering the deep Tethys Ocean (Fig. 2).

The giant limulid trackway was found in the lower Lithographic Limestones. It was uncovered at the end of the scientific work at the extreme base of the studied section where it is preserved on the top surface of an unnumbered bed. Successive parts of the trackway and all individual tracks were photographed. A silicone cast of the whole trackway was made in situ in order to obtain a resin replica for laboratory studies. Then, the bed bearing the trackway was collected. The original trackway and its resin replica are housed in the Collections de Géologie de l'Université de Lyon (original $=\mathrm{n}^{\circ}$ FSL 504919 a, resin replica $=\mathrm{n}^{\circ}$ FSL 504919 b). Measurements of the whole trackway were made, using, after modification, the methodologies proposed for locomotion traces of arthropods (Trewin 1994; Braddy 2001) and vertebrate tetrapods (Haubold 1971; Leonardi 1987).

The limulid trackway was situated at the top of a thin, $1.25 \mathrm{~mm}$ thick limestone bed. It clearly corresponds to an epichnion, more precisely to an epichnial groove (Martinsson 1970). Goldring and Seilacher (1971) consider 


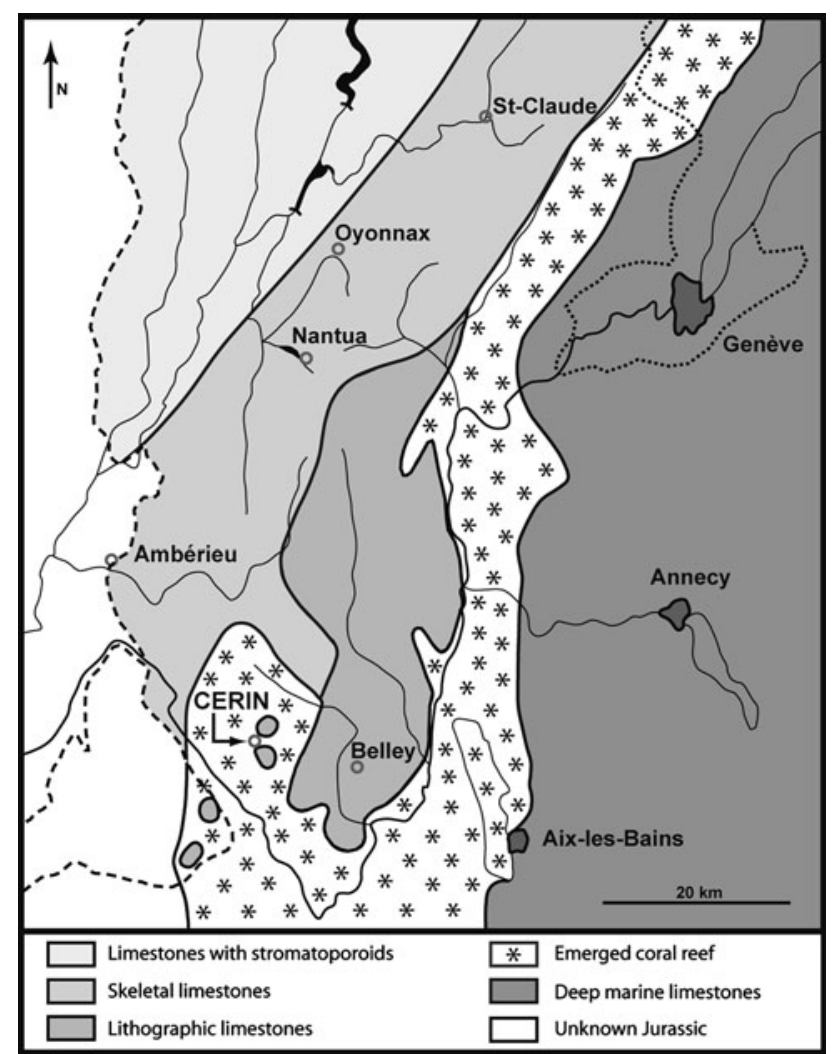

Fig. 2 Palaeogeography of the Southern Jura area during the Late Kimmeridgian (modified after Bernier 1984). The Cerin Lagerstätte corresponds to a small, isolated, marginal marine lagoon

that limulid trackways are commonly made of undertracks. The presence of undertracks is not so easy to prove as noted by Romano and Whyte (2003) and no evidence of such tracks has been found when studying the trackway. Moreover, the presence of surface tracks is likely in the studied case because the calcareous mud of the Cerin lagoon was commonly covered by a microbial mat providing a cohesive substrate. The occurrence of microbial mats is clearly proven for the Cerin Lagerstätte and they have a very important influence on taphonomy (Gall et al. 1985; Gaillard et al. 2006). The occurrence of microbial mats at the top of the bed containing the studied trackways is possible but, however, not really proven.

\section{Taxonomic considerations}

The systematic ichnology of limulid tracks is not straight forward, because diverse behaviours are commonly documented by traces which exhibit a wide morphological diversity. For example, these behaviours may form resting traces (Miller 1982), successions of resting traces (Hardy 1970; Eagar et al. 1985), slight burrowing activity (Romano and Whyte 1987; Wang 1993), regular locomotion (Oppel
1862; Nopsca 1923; Nielsen 1949; Kolb 1963; Frickhinger 1994; Schweigert 1998; Harris and Lacovara 2004) or slow dying locomotion (Malz 1964; Groiss 1975; Barthel 1978; Barthel et al. 1990; Frickhinger 1994). The preservation of these traces is often poor and, frequently, only more or less hazy trackways occur (Packard 1900; Bandel 1967; Chisholm 1983; Conti et al. 1991; Buatois et al. 1998; Harris and Lacovara 2004). As a consequence a considerable confusion surrounds the taxonomy of limulid traces and several ichnogenera have been proposed: Kouphichnium Nopsca 1923; Micrichnus Abel 1926; Artiodactylus Abel 1926, Hypornithes Jaekel 1929; Ornichnites Jaekel 1929; Protornis Jaekel 1929; Paramphibius Willard 1935; Limuludichnulus Linck 1943; Limuludichnus Linck 1949, Limulicubichnus Miller 1982; Selenichnus Romano and Whyte 1987; Selenichnites Romano and Whyte 1990. Most of the older ichnogenera are now considered as synonyms of Kouphichnium (Häntzschel 1975) which is actually the most widely used ichnotaxon covering a large morphological variability.

\section{Ichnogenus Kouphichnium Nopsca 1923}

Type ichnospecies Kouphichnium lithographicum (Oppel 1862)

In spite of some differences, the trackway described in this paper is rather similar to the type specimen illustrated by Oppel (1862) and can be related to the ichnogenus Kouphichnium. This ichnotaxon is relatively complex and its characterization is not easy because, as noted by Häntzschel (1975), it is a "heteropodous track of great variability". It corresponds to a complete or incomplete assemblage of very different traces made by different appendages which include two types of walking legs and a sword-like telson.

The ichnogenus Kouphichnium was introduced by Nopsca (1923) for very regular locomotion traces previously described by Oppel (1862) under the name "Ichnites lithographicus". The type species was discovered in the Upper Jurassic Solnhofen Lithographic Limestones (Bavaria, Germany) and was cited under different names such as "Ichnites lithographica" or "Ichnium lithographicum" (see Walther 1904). The ichnogenus Kouphichnium was later used for a wide range of traces made by limulids. For example, Hardy (1970) used the name Kouphichnium rossendalensis to describe very different trackways composed of a succession of resting traces. To clarify this problem, Romano and Whyte $(1987,1990)$ introduced the ichnogenus Selenichnites for traces characterized by a lunate part resulting from burrowing activity. Limulicubichnus is a true limulid resting trace (Miller 1982). All other above-cited ichnogenera may be considered as junior 
synonyms of Kouphichnium or they are invalid as in the case of Selenichnus (Romano and Whyte 1990).

\section{Ichnospecies Kouphichnium lithographicum (Oppel 1862)}

This ichnospecies was first proposed for simple straight locomotion traces found in the Solnhofen area. The type ichnospecies described by Oppel (1862) exhibits a median groove and repeated series of imprints including, on each side, a complex trifid imprint and only one simple imprint. Then, the famous traces with the dead limulid Mesolimulus walchi (Desmarest 1822) at the end have been described from the same Upper Jurassic deposits. These mortichnia have been consequently named Kouphichnium walchi by Malz (1964). This usage has some followers: for example, Groiss (1975) described a trackway referred to Kouphichnium (Mesolimulus) walchi. This ichnospecies is a curved complex trackway characterized by frequent disrupted imprints of the telson. Numerous trackways with intermediate characteristics have been discovered in the lithographic limestones from the Solnhofen area showing that the use of two distinct ichnotaxa is probably not a good choice. The limulid trackway from the lithographic limestones of Cerin is assigned to Kouphichnium lithographicum because it clearly corresponds to a simple straight locomotion trace.

Kouphichnium variabilis (Linck 1949) is a complex, variably defined ichnospecies (Romano and Whyte 2003) and Kouphichnium rossendalensis Hardy 1970 is a succession of resting traces now related to the ichnogenus Selenichnites (Romano and Whyte 1987, 1990). Other ichnospecies such as K. didactylus (Willard 1935), K. arizonae Caster 1944, K. gracilis (Linck 1949), and K. cordiformis Fischer 1978 are also quite different.

\section{Trackway description}

Kouphichnium is characterized by strongly heteropodous tracks because limulids have six pairs of appendages including a pair of chelicers and five heterogeneous pairs of legs (Størmer 1955; Malz 1964; Fig. 3). The pair of chelicers (I) is the smallest and is used only for ingestion whereas the next five pairs (II-VI) are mainly used for locomotion. Like chelicers, legs are chelate (II-V) except for the last pair (VI). The first pair (II) is smaller and corresponds to pedipalps. The next three pairs (III-V) are true walking legs. The last pair (VI) corresponds to complex legs which are used for locomotion as active "pushers" but also for digging. These hind-legs which are typical of horseshoe crabs have additional segments forming a fan-shaped structure. Limulids are also characterized by a two-part body consisting of a prosoma (head part) and an opisthosoma (abdominal part) ending in a long

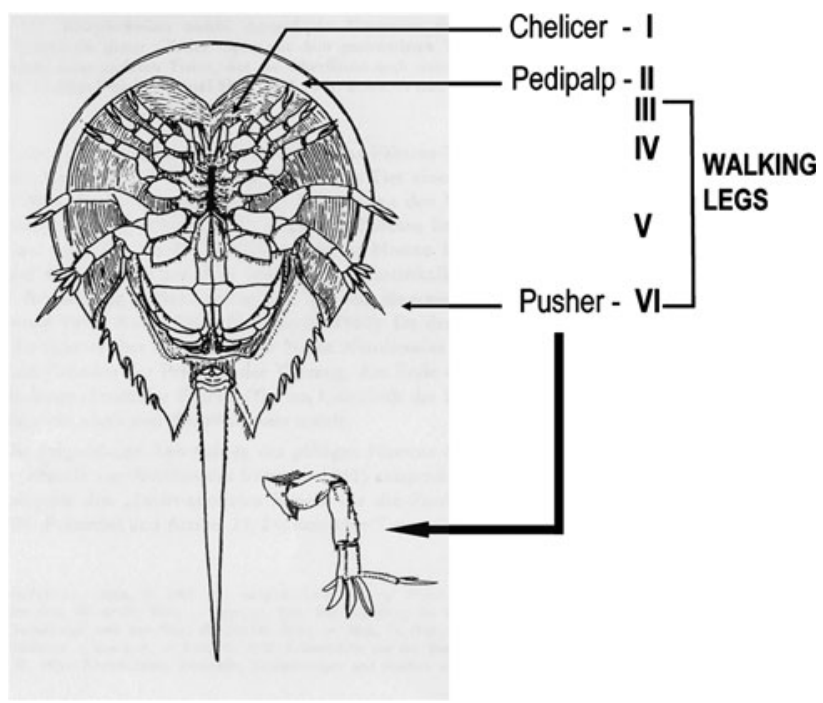

Fig. 3 Ventral view of a living limulid showing the different appendages (after Malz 1964). The leg VI, named "pusher" is detailed in another position

telson. Prosoma and telson are also potential trace-making organs.

The morphology of a complete or ideal trackway is now well established based on fossil and recent observations (Caster 1944). It is composed of two main lateral imprints (legs VI = "pushers"), eight small intermediate imprints (legs II-V), and one axial median imprint (telson). This pattern differs from the holotype drawn by Oppel (1862) which shows two main lateral imprints, only two small intermediate imprints, and one axial median imprint. Kouphichnium observed in the Upper Jurassic Lithographic Limestones of Cerin is an intermediate form between the two.

The studied trackway exhibits only tracks without any telson and prosoma imprints. It is a symmetric trackway exhibiting ten sets of imprints (Fig. 4). Each set shows a pair of well preserved main imprints and a variable number (mostly three pairs) of discrete intermediate imprints. The whole trackway is straight and three meters long. Several parameters have been measured (Figs. 5, 6). The internal width is $178 \mathrm{~mm}$ and the external width is $258 \mathrm{~mm}$ (Table 1). The mean stride or repeat distance is $314 \mathrm{~mm}$ (Table 2). The average series length is $343 \mathrm{~mm}$ (Table 3) and the mean set overlap is $6 \mathrm{~mm}$ (Table 4). The spacing of intermediate imprints is $89.5 \mathrm{~mm}$ (Table 5). The angle of intermediate imprints to the mid-line is $14^{\circ}$ (Table 6).

Main imprints or "pusher imprints"

These are the largest and the most external imprints of the trackway. In a set, two main imprints are symmetrically opposed and clearly correspond to the pushers (leg VI). 
Fig. 4 Schematic drawing of the whole trackway with numbering of sets. The detailed photographic part shows some imprints of the series numbered L3 and L4 on the left side of the trackway

Fig. 5 Section of the trackway showing four pusher imprints and specifying the measurement of external width, internal width, and stride. Pusher imprints come from sets 3 and 4
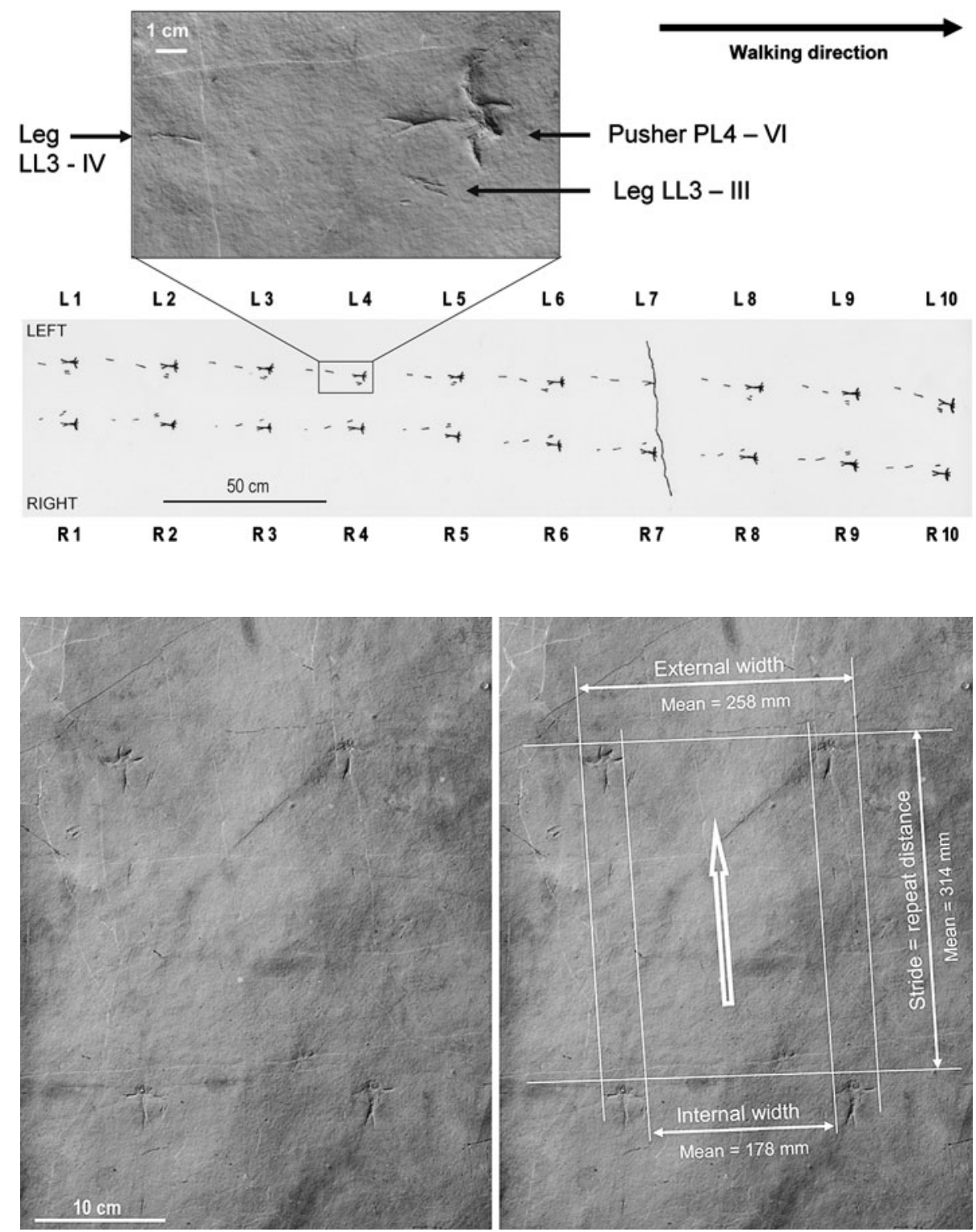

These imprints exhibit a tetradactyl or 'quadrifid' wide anterior part and a didactyl or 'bifid' posterior part (Fig. 7). The four digit-like protuberances point forward and clearly correspond to the four blade-like appendices which characterize the anterior fan-structure of the hind-leg. The external digit is the longest. The posterior part is a thin elongate mark ending in a bifid tail. It corresponds to the longest and narrowest bifid segment which characterizes the extremity of the hind-leg. Three parameters have been measured (Fig. 8, Table 7). The mean width is $40.2 \mathrm{~mm}$ (37-44 $\mathrm{mm})$ and the mean length is $45.8 \mathrm{~mm}(40-50 \mathrm{~mm})$. The mean angle between the two parts of the bifid tail is $30.4^{\circ}\left(28^{\circ}-42^{\circ}\right)$.

The tetradactyl or quadrifid aspect of the anterior part is quite original. The initial drawing of Oppel (1862) for
Kouphichnium lithographicum only shows three digits. The drawing of Caster (1944) shows also a trifid part but with only one "digit" pointing forward. But some other prints are rather similar with four "digits" pointing forward, for example those illustrated by Schweigert (1998, Taf. 10, p. 47 and the very schematic drawing of Fig. 5, p. 18), the specimen illustrated by Kolb (1963), some specimens described as a "digitate track with four acuminate rays" by Nielsen (1949), pusher traces of the trackway described by Oishi et al. (1993), and even some specimens illustrated by Harris and Lacovara (2004, Fig. 5). The quite similar pusher imprint is shown by Kouphichnium lithographicum from the Upper Jurassic Nusplinger Plattenkalk (Schweigert and Dietl 2002). Imprints from Cerin never show five digits as seen in some Devonian limulid imprints reported as Paramphibius. 


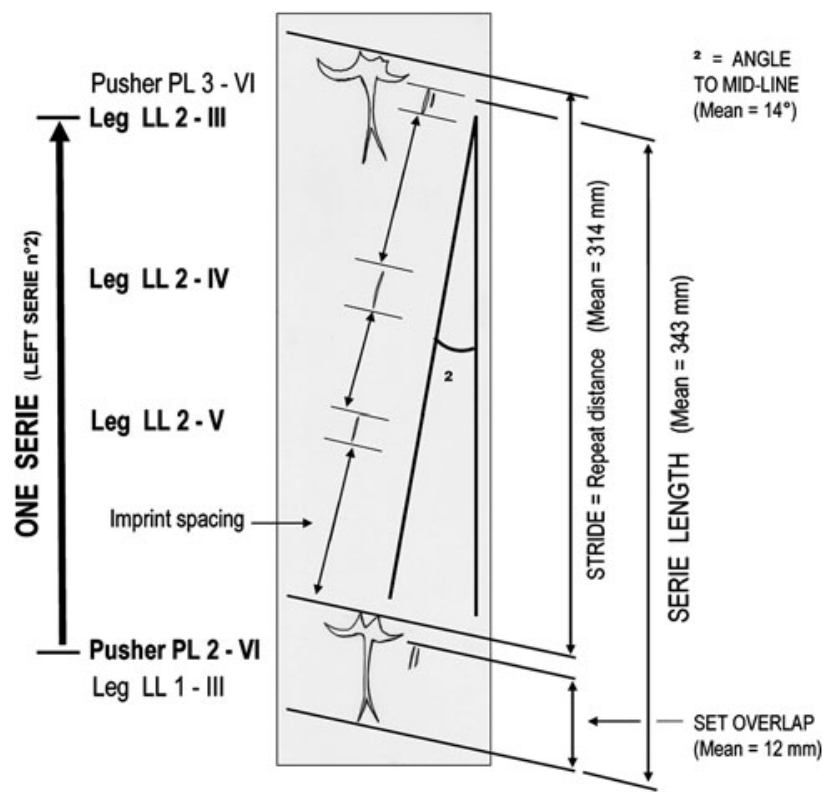

Fig. 6 Schematic drawing specifying the numbering of prints and the measurement of imprint spacing, serie length, stride, set overlap and angle to mid-line

Table 1 Measurements of internal width and external width of the trackway

\begin{tabular}{lll}
\hline & Internal width $(\mathrm{mm})$ & External width $(\mathrm{mm})$ \\
\hline R1-L1 & 175 & 257 \\
R2-L2 & 176 & 260 \\
R3-L3 & 178 & 258 \\
R4-L4 & 182 & 260 \\
R5-L5 & 179 & 258 \\
R6-L6 & 177 & 260 \\
R7-L7 & $?$ & 258 \\
R8-L8 & 178 & 257 \\
R9-L9 & 180 & 259 \\
R10-L10 & 179 & 260 \\
Mean & 178.2 & 258.7 \\
\hline
\end{tabular}

? data non available

Intermediate imprints or "simple tracks"

Three pairs of small intermediate imprints are visible in a set. They are elongate imprints appearing as single (IV, V) or eventually double scratch marks (III). The mean length of these imprints is $11.7 \mathrm{~mm}$ (Table 8). They are straight and very slightly oblique (mean angle to mid-line: $14^{\circ}$ ). These elongate imprints differ strongly from the circular or ellipsoidal imprints drawn by Oppel (1862) for Kouphichnium lithographicum and by Caster (1944). Double scratches underline the chelate nature of walking legs (Fig. 8). V-shaped furrows as observed by Schweigert (1998) are not present. The occurrence of three pairs of
Table 2 Measurements of repeat distances (stride)

Table 3 Measurements of series length

\begin{tabular}{ll}
\hline \multicolumn{2}{l}{ Stride-repeat distance (mm) } \\
\hline Right \\
R1-R2 & 332 \\
R2-R3 & 318 \\
R3-R4 & 327 \\
R4-R5 & 334 \\
R5-R6 & 314 \\
R6-R7 & 330 \\
R7-R8 & 338 \\
R8-R9 & 322 \\
R9-R10 & 343 \\
Left & \\
L1-L2 & 334 \\
L2-L3 & 328 \\
L3-L4 & 322 \\
L4-L5 & 332 \\
L5-L6 & 350 \\
L6-L7 & 330 \\
L7-L8 & 341 \\
L8-L9 & 338 \\
L9-L10 & 314 \\
Mean & 314.8 \\
\hline
\end{tabular}

\begin{tabular}{ll}
\hline Series length (mm) \\
\hline Right \\
SR 1 & 333 \\
SR 2 & 333 \\
SR 3 & 340 \\
SR 4 & 347 \\
SR 5 & 330 \\
SR 6 & 345 \\
SR 7 & 345 \\
SR 8 & 344 \\
SR 9 & 348 \\
Left & \\
SL 1 & 347 \\
SL 2 & 352 \\
SL 3 & 347 \\
SL 4 & 352 \\
SL 5 & 353 \\
SL 6 & 340 \\
SL 7 & 348 \\
SL 8 & 356 \\
SL 9 & 327 \\
Mean & 343.7 \\
\hline
\end{tabular}


Table 4 Measurements of set overlaps

imprints indicates a significant difference from the initial drawing of Oppel (1862) for Kouphichnium litographicum where only one pair is present. By contrast, the ideal set of Caster (1944) exhibits four pairs of intermediate imprints. Caster (1944) also noted that the first pair corresponding to pedipalps (legs II) is rarely preserved. The drawing of Abel (1926) for Kouphichnium lithographicum also illustrates only three pairs. Therefore, these imprints probably correspond to the walking legs III, IV and V.

Median imprint

The axial imprint, which is present in the type ichnospecies of Kouphichnium lithographicum, is completely absent in the studied trackway, indicating that the telson was not in contact with the sediment.

\section{Size of the trackmaker}

The size of the trackmaker can be deduced from the external width of the trackway. For this, the model proposed by Malz (1964) for limulids was used (Fig. 9a). It is based on data from Caster (1944), Størmer (1952) and Seilacher (1959) and leads to the following simple formula, $\mathrm{I}=\mathrm{W} \times 1.5$ where $\mathrm{I}$ is the width of the prosoma of the
Table 5 Measurements of imprint spacings

\begin{tabular}{|c|c|c|c|}
\hline \multicolumn{4}{|l|}{ Imprint spacing (mm) } \\
\hline \multicolumn{2}{|l|}{ Right } & \multicolumn{2}{|l|}{ Left } \\
\hline \multicolumn{2}{|l|}{$\begin{array}{l}\text { Right } \\
\text { PR 1-VI-LR 1-V }\end{array}$} & PL 1-VI-LL 1-V & 119 \\
\hline $\begin{array}{l}\text { PR 1-VI-LR 1-V } \\
\text { LR 1-V-LR 1-IV }\end{array}$ & 59 & LL 1-V-LL 1-IV & 75 \\
\hline \multirow{2}{*}{$\begin{array}{l}\text { LR 1-IV-LR 1-III } \\
\text { PR 2-VI-LR 2-V }\end{array}$} & 72 & LL 1-IV-LL 1-III & 79 \\
\hline & 110 & PL 2-VI-LL 2-V & 112 \\
\hline \multirow{2}{*}{$\begin{array}{l}\text { LR 2-V-LR 2-IV } \\
\text { LR 2-IV-LR 2-III }\end{array}$} & 72 & LL 2-V-LL 2-IV & 93 \\
\hline & 77 & LL 2-IV-LL 2-III & 74 \\
\hline \multirow{2}{*}{$\begin{array}{l}\text { PR 3-VI-LR 3-V } \\
\text { LR 3-V-LR 3-IV }\end{array}$} & 130 & PL 3-VI-LL 3-V & 110 \\
\hline & 58 & LL 3-V-LL 3-IV & 75 \\
\hline LR 3-IV-LR 3-III & 80 & LL 3-IV-LL 3-III & 78 \\
\hline \multirow{2}{*}{$\begin{array}{l}\text { PR 4-VI-LR 4-V } \\
\text { LR 4-V-LR 4-IV }\end{array}$} & 125 & PL 4-VI-LL 4-V & 118 \\
\hline & 79 & LL 4-V-LL 4-IV & 72 \\
\hline LR 4-IV-LR 4-III & 82 & LL 4-IV-LL 4-III & 82 \\
\hline PR 5-VI-LR 5-V & 108 & PL 5-VI-LL 5-V & 127 \\
\hline LR 5-V-LR 5-IV & 72 & LL 5-V-LL 5-IV & 72 \\
\hline LR 5-IV-LR 5-III & 73 & LL 5-IV-LL 5-III & 79 \\
\hline PR 6-VI-LR 6-V & 132 & PL 6-VI-LL 6-V & 91 \\
\hline LR 6-V-LR 6-IV & 62 & LL 6-V-LL 6-IV & 101 \\
\hline LR 6-IV-LR 6-III & 79 & LL 6-IV-LL 6-III & 70 \\
\hline PR 7-VI-LR 7-V & 108 & PL 7-VI-LL 7-V & 123 \\
\hline LR 7-V-LR 7-IV & 68 & LL 7-V-LL 7-IV & 78 \\
\hline LR 7-IV-LR 7-III & 80 & LL 7-IV-LL 7-III & 90 \\
\hline PR 8-VI-LR 8-V & 112 & PL 8-VI-LL 8-V & 119 \\
\hline LR 8 V-LR 8-IV & 74 & LL 8-V-LL 8-IV & 76 \\
\hline LR 8-IV-LR 8-III & 80 & LL 8-IV-LL 8-III & 82 \\
\hline PR 9-VI-LR 9-V & 135 & PL 9-VI-LL 9-V & 96 \\
\hline LR 9-V-LR 9-IV & 57 & LL 9-V-LL 9-IV & 79 \\
\hline LR 9-IV-LR 9-III & 80 & LL 9-IV-LL 9III & 75 \\
\hline Mean & 88.4 & & 90. \\
\hline
\end{tabular}

trackmaker and $\mathrm{W}$ the external width of the trackway. Using this formula, the width of the prosoma of the limulid of Cerin is $387 \mathrm{~mm}$. When considering the mean proportions of extant animals, for example Limulus polyphemus (Fig. 9b), the total length of the animal corresponds to the width of the prosoma multiplied by 2.12 . Using this formula $(\mathrm{L}=\mathrm{I} \times 2.12)$, the length of the trackmaker could be $820 \mathrm{~mm}$. The mean proportions of other extant species (Carcinoscorpius rotundicaudata, Tachypleus gigas and Tachypleus tridentatus) are very similar with L/l ranging from 2 to 2.2 (Sekiguri 1988). The length of the limulid from Cerin probably ranges from 774 to $851 \mathrm{~mm}$.

The size of the studied limulid is indubitably very important. First, it is larger than all limulids known from the recent. Among living species (Carcinoscorpius rotundicaudata, Limulus polyphemus, Tachypleus gigas and Tachypleus tridentatus), T. gigas is the largest with a carapace width reaching $250 \mathrm{~mm}$ (Vijayakumar et al. 2000). 

angles to mid-line
Table 6 Measurements of

\begin{tabular}{ll}
\hline Angle to mid-line $\left(^{\circ}\right)$ & \\
\hline Right & \\
R1-R2 & $15^{\circ}$ \\
R2-R3 & $15^{\circ}$ \\
R3-R4 & $12^{\circ}$ \\
R4-R5 & $14^{\circ}$ \\
R5-R6 & $12^{\circ}$ \\
R6-R7 & $14^{\circ}$ \\
R7-R8 & $13^{\circ}$ \\
R8-R9 & $15^{\circ}$ \\
R9-R10 & $15^{\circ}$ \\
Left & \\
L1-L2 & $15^{\circ}$ \\
L2-L3 & $14^{\circ}$ \\
L3-L4 & $13^{\circ}$ \\
L4-L5 & $15^{\circ}$ \\
L5-L6 & $15^{\circ}$ \\
L6-L7 & $16^{\circ}$ \\
L7-L8 & $16^{\circ}$ \\
L8-L9 & $13^{\circ}$ \\
L9-L10 & $15^{\circ}$ \\
Mean & $14.2^{\circ}$ \\
\hline
\end{tabular}

Females are larger than males. For example, concerning Limulus polyphemus, the mean prosomal width is $220 \mathrm{~mm}$ for females and $166 \mathrm{~mm}$ for males (Shuster 1982). Fossil limulids are never very long and the width of the carapace rarely reaches $200 \mathrm{~mm}$. Many fossil limulids are only a few centimetres long (Hardy 1970; Riek and Gill 1971; Pickett 1984; Babcock et al. 2000). Heterolimulus gadeai is a large limulid from the Triassic of Spain, but the width of the carapace is smaller than $200 \mathrm{~mm}$ (Via Boada and de Villalta 1966). Siveter and Selden (1987) described a giant xiphosurid from the lower Namurian and wrote that it was one of the largest specimens known from the fossil record but the width of the carapace only reaches approximately $150 \mathrm{~mm}$. These authors also stated that only Tachypleus decheni (Zincken 1862) from the German Miocene is larger (Böhm 1905). Jurassic limulids from lithographic limestones (Mesolimulus walchi) exhibit also a relatively large width of up to $235 \mathrm{~mm}$ in the Solnhofen Lagerstätte and ranging from 90 to $160 \mathrm{~mm}$ in the Cerin Lagerstätte (Gall et al. 1996). The tertiary trackway described by Oishi et al. (1993) and re-illustrated by Lockley and Matsukawa (2009) averages $246 \mathrm{~mm}$ in width.

The size of limulid trace fossils leads to the same conclusions. Limulids resting traces provide direct information about the prosoma width. It is 16 to $17 \mathrm{~mm}$ (Hardy 1970), $28 \mathrm{~mm}$ (Eagar et al. 1985), up to $110 \mathrm{~mm}$ (Miller 1982) for Carboniferous specimens and $70-80 \mathrm{~mm}$ for Rhaetian specimens (Wang 1993). When considering the described trackways, their external width is never very large. Measurements from the literature are for example 19.6-51.1 mm in Carboniferous deposits (Buatois et al. 1998), 35-75 mm in Triassic deposits (Nielsen 1949), and $170 \mathrm{~mm}$ in Middle Jurassic deposits (Romano and Whyte 2003). The width of the similar pusher imprints is only 6.9-12.6 mm (Buatois et al. 1998) and 11-18 mm (Nielsen 1949). Only Late Jurassic limulid traces from France and Germany and the Oligocene example from Japan indicate much larger sizes. Solnhofen mortichnia are relatively narrow, with an external width of about $100 \mathrm{~mm}$ (Groiss 1975) but some other locomotion traces are wider. For example, Kolb (1963), Schweigert (1998) and Frickhinger (1994) noted the occurrence of trackways, respectively, 225, 260, and $330 \mathrm{~mm}$ wide from Solnhofen and Nusplingen Lithographic Limestones. The pusher imprint schematically drawn by Schweigert (Schweigert 1998, Fig. 5) is probably one of the largest previously described (35 mm width). The average width of the pusher imprints is about $40 \mathrm{~mm}$ in the studied trackway from Cerin. Clearly, Late Jurassic limulids from Lithographic Limestones of Germany (Solnhofen, Nusplingen) and France (Cerin) are giant limulids.

\section{Behavioural considerations}

The absence of median imprint clearly documents that the telson has not been in contact with the sea floor. The total absence of imprints of the telson and also of the prosoma indicates an underwater trace made by walking on the sea floor. Only locomotion appendages are used. The very well marked imprints of hind legs underline the main role of the "pushers" for locomotion. Its anterior digital aspect indicates a clear support by the fan structure of this specialized leg. The bifid aspect of the prints posterior part also proves the contact to the sea floor of the whole two parts of the opposite longer segment. The print of all these segments indicates that anterior and posterior segments of the pushers are shallower impressed as previously noted by Caster (1944) for some kinds of limulid imprints. By contrast, the intermediate imprints have probably a minor role because they are small and the traces are very discrete.

Their elongate straight shape indicates a light contact with the sea floor and not a true support. The very regular repetition of the imprints probably resulted from normal locomotion. The significant distance between two pairs of pushers imprints (repeat distance) indicates that locomotion was efficient and probably rather rapid. Fast locomotion is also suggested by the very straight line of the trackway. All these aspects could characterize a normal, but fast locomotion by walking on the sea floor. These ichnological deductions are fully consistent with personal 

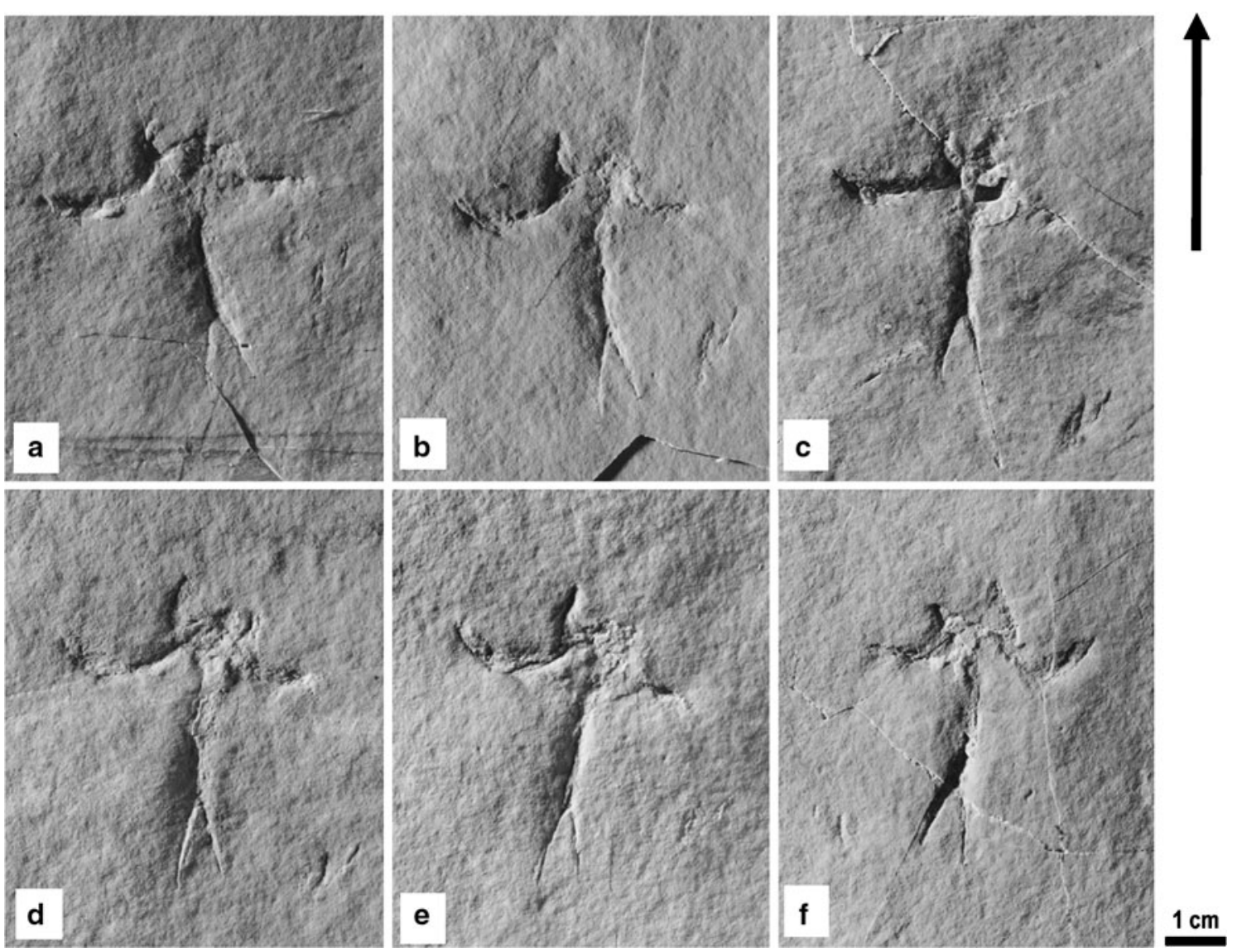

Fig. 7 Six pusher imprints showing the four digit anterior part and the long bifid posterior part. a PL1; b PL2; c PL6; d PL8; e PL9; f PR5. The longer digit of the anterior part points out of the trackway. The arrow indicates the walking direction

observations made on a living adult of Limulus polyphemus in an aquarium. Swimming corresponds to another fast locomotion of limulids. Indeed, limulids can swim upsidedown, using their book gills to propel themselves through the water (Shuster and 1982) but then they probably do not produce traces or quite different ones.

The studied trackway fundamentally differs from the famous mortichnia of Solnhofen. These mortichnia are not straight, but strongly meandering and characterized by a short repeat distance, well marked telson imprints, occasionally prosoma imprints and poorly-preserved leg imprints. Walking legs, and notably pushers, provide poorly preserved imprints because of their probable oblique position relative to the sea floor, and because of the reduced stride. By comparison, it is assumed that the flat 'plantigrade' impression of the pushers, the absence of the contact of the telson with the sea floor and the large repeat distance are the main characteristics of a normal, but fast locomotion. At least, when considering the previously described trackways, four main types of clear limulid traces could be proposed (Fig. 10):
1. Walking trackways: characterized by prints of legs (pushers and other legs) only. The stride is long and the angle to the midline is small. The animal walks relatively fast on the sea-floor. The studied trackway from Cerin, some Jurassic Kouphichnium lithographicum from Solnhofen (Schweigert 1998) and the Oligocene trackway from Japan (Oishi et al. 1993) are typical walking trackways.

2. Crawling trackways: characterized by prints of both, legs and telson. The stride is short and the angle to midline is high. The animal crawls slowly grooving the sediment with its telson. Some Jurassic Kouphichnium lithographicum from Solnhofen (Kolb 1963) are good examples.

3. Trackways of dying limulids (mortichnia): characterized by prints of legs, telson, and prosoma. The prints of legs are close scratches and the prosoma is slightly marked. The print of the telson is well marked. The trackway is sinuous and ends with the whole limulid imprint. This type of crawling characterizes the slow last locomotion trace made by a dying animal. The 


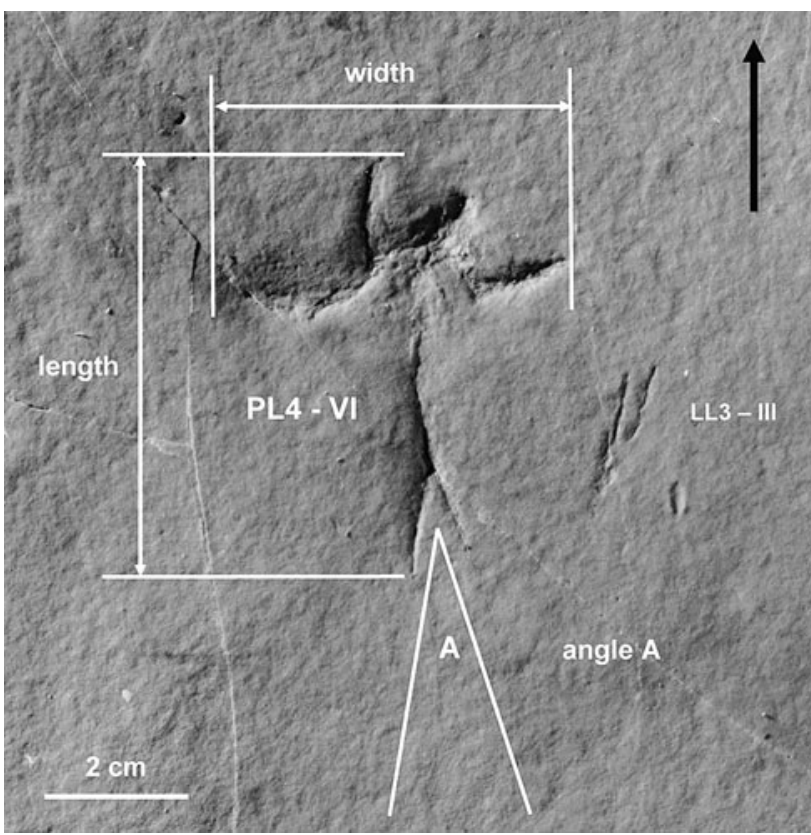

Fig. 8 Morphology of a pusher imprint and measurement of length, width and angle formed by the bifid posterior part. The picture shows the pusher imprint PL4-VI and the double scratched leg imprint LL3III. The arrow indicates the walking direction

resulting trace is a typical mortichnia. The best example is Kouphichnium walchi, a Jurassic trackway from Solnhofen (Barthel 1978; Barthel et al. 1990).

4. Ploughing trackways: mainly characterized by deep prints of the prosoma. Telson traces may be poorly impressed and leg traces indistinct. The traces clearly indicate a superficial ploughing of the sediment. The recent species Limulus polyphemus commonly shows this behaviour (Eldredge 1970). The Carboniferous
Limulicubichnus rossendalensis (Hardy 1970) and the Jurassic Selenichnites hundalensis (Romano and Whyte 1987, 1990) provide good fossil examples.

Parameters usually visible in limulid trackways and supporting this classification are listed and characterized in Table 9. Trackways considered in this classification certainly do not illustrate all locomotion activities of limulids. For example, crawling traces of juvenile limulids may have a very different Nereites-like morphology (Babcock et al. 2000; Martin and Rindsberg 2007). Of course, limulids also commonly swim without leaving traces on the sea floor (Shuster and 1982; Vosatka 1970).

\section{Environmental considerations}

Recent limulids are marine animals living in beach (spawning) to continental shelf (Shuster and 1982; Sekiguri 1988) environments. Many ancient limulids from Paleozoic and Triassic times are considered as freshwater animals because they are commonly found in continental deposits. Indeed, they are known from lacustrine, estuarine, and deltaic environments (Willard 1935; Caster, 1944; Bandel 1967; Hardy 1970; Eagar et al. 1985; Buatois et al. 1998; Babcock et al. 2000). Since the Jurassic, marine occurrences of limulids are commonly reported, and limulids in freshwater settings are still well established during the Cretaceous (Riek and Gill, 1971). These occurrences are related to episodic marine influences on a coastal plain (Romano and Whyte 2003) or tidal flat environments (Harris and Lacovara 2004). It is well established that, like Solnhofen, the Cerin lagoon represents a marginal marine environment. As a consequence, limulids from Cerin like recent

Table 7 Measurements of length, width and angle A of pushers

\begin{tabular}{|c|c|c|c|c|c|c|c|}
\hline Right & Length L (mm) & Width w (mm) & Angle A $\left(^{\circ}\right)$ & Left & Length L (mm) & Width w $(\mathrm{mm})$ & Angle A $\left(^{\circ}\right)$ \\
\hline PR 1 & 46 & 38 & 30 & PL 1 & 40 & 44 & 33 \\
\hline PR 2 & 45 & 42 & 29 & PL 2 & 46 & 42 & 30 \\
\hline PR 3 & 46 & 40 & 30 & PL 3 & 47 & 40 & 29 \\
\hline PR 4 & 45 & 37 & 32 & PL 4 & 49 & 41 & 30 \\
\hline PR 5 & 50 & 38 & 31 & PL 5 & 49 & 41 & 24 \\
\hline PR 6 & 41 & 41 & 31 & PL 6 & 46 & 42 & 26 \\
\hline PR 7 & 46 & 39 & 30 & PL 7 & $?$ & $?$ & 28 \\
\hline PR 8 & 47 & 39 & 30 & PL 8 & 48 & 40 & 30 \\
\hline PR 9 & 44 & 41 & 32 & PL 9 & 47 & 38 & 30 \\
\hline PR 10 & 44 & 41 & 31 & PL 10 & 45 & 40 & 42 \\
\hline Mean & 45.4 & 39.6 & 30.6 & Mean & 46.3 & 40.8 & 30.2 \\
\hline
\end{tabular}

$P$ Pushers 
Table 8 Measurements of length of leg imprints with indication of bifid imprints (b)

\begin{tabular}{|c|c|c|c|}
\hline Right & Length L (mm) & Left & Length $\mathrm{L}(\mathrm{mm})$ \\
\hline LR 1-V & 10 & LL 1-V & 10 \\
\hline LR 1-IV & 17 & LL 1-IV & 14 \\
\hline LR 1-III & $12 \mathrm{~b}$ & LL 1-III & $15 \mathrm{~b}$ \\
\hline LR 2-V & 8 & LL 2-V & 6 \\
\hline LR 2-IV & 10 & LL 2-IV & 13 \\
\hline LR 2-III & $18 \mathrm{~b}$ & LL 2-III & $15 \mathrm{~b}$ \\
\hline LR 3-V & 7 & LL 3-V & 6 \\
\hline LR 3-IV & 14 & LL 3-IV & 20 \\
\hline LR 3-III & 11 & LL 3-III & $17 \mathrm{~b}$ \\
\hline LR 4-V & 8 & LL 4-V & 11 \\
\hline LR 4-IV & 11 & LL 4-IV & 17 \\
\hline LR 4-III & $9 \mathrm{~b}$ & LL 4-III & $14 \mathrm{~b}$ \\
\hline LR 5-V & 4 & LL 5-V & 9 \\
\hline LR 5-IV & 16 & LL 5-IV & 11 \\
\hline LR 5-III & 12 & LL 5-III & $12 \mathrm{~b}$ \\
\hline LR 6-V & 10 & LL 6-V & 6 \\
\hline LR 6-IV & 15 & LL 6-IV & 16 \\
\hline LR 6-III & $6 \mathrm{~b}$ & LL 6-III & 13 \\
\hline LR 7-V & 9 & LL 7-V & 7 \\
\hline LR 7-IV & 17 & LL 7-IV & 6 \\
\hline LR 7-III & $11 \mathrm{~b}$ & LL 7-III & $10 \mathrm{~b}$ \\
\hline LR 8-V & 6 & LL 8-V & 10 \\
\hline LR 8-IV & 18 & LL 8-IV & 20 \\
\hline LR 8-III & $14 \mathrm{~b}$ & LL 8-III & $10 \mathrm{~b}$ \\
\hline LR 9-V & 14 & LL 9-V & 6 \\
\hline LR 9-IV & 20 & LL 9-IV & 14 \\
\hline LR 9-III & $14 \mathrm{~b}$ & LL 9-III & $16 \mathrm{~b}$ \\
\hline Mean & 11.8 & & 11.6 \\
\hline
\end{tabular}

$L$ legs, $b$ bifid

limulids are probably true marine animals. Fossil freshwater limulids are generally smaller than marine limulids (Hauschke and Wilde 1991) and this is also consistent with the large size of the limulids from Cerin. Recent limulids show some euryhaline tendencies (Shuster and 1982) and this is also consistent with possible salinity conditions in the marginal marine environment of Cerin.

Most of the fossilized animals of Cerin came from various environments, and were occasionally introduced and gathered in the lagoon where they died after a relatively short time in poisonous water (Barale et al. 1985; Bernier and Gaillard 1990). According to this hypothesis, adult limulids could have been passively introduced into the lagoon. The occurrence of a large adult rapidly walking on the sea floor of the Cerin lagoon and the absence of limulid mortichnia probably illustrates short-term favourable environmental conditions allowing benthic life. This situation could correspond to short periods with a better connection between the open sea and the lagoon. This is a clear difference to the Solnhofen lagoon where juveniles are commonly preserved at the end of their mortichnia indicating that the environment was hostile (Seilacher 2007).

Fossil limulids from Cerin are rare. They were not discovered while the Lithographic Limestones of Cerin were intensively quarried and Van Straelen (1924) noted the total absence of limulids. Only two poorly-preserved specimens of Mesolimulus walchi were recently collected during the scientific excavation (Gall et al. 1996). At least, two specimens are known as body fossils and only one as trace fossil (this paper). All have been discovered at the base of the Lithographic Limestones. This clearly confirms the previously supposed history of the Cerin lagoon with early dominant marine influences marked by jellyfish, fish and ammonites and later dominant terrestrial influences marked by autochthonous marginal marine burrows (Tubularina lithographica) and allochthonous terrestrial plants (Zamites) (Gaillard et al. 2006). Nevertheless, the rare occurrence of limulids suggests the generally very poor connection between the Cerin lagoon and the open sea.

Recent limulids feed mainly on bivalves but also on polychaete worms that they dig out of the sediment (Shuster and 1982; Botton 1984; Botton and Ropes 1989; Botton et al. 2003). Infaunal bivalves are extremely rare in the Lithographic Limestone Unit of Cerin and polychaete worms, which are the probable trace makers of Tubularina, occur only in the upper part (Gaillard et al. 1994b), where limulids are absent. Probably, limulids, like many other organisms found in the Lithographic Limestones, did not habitually live in the Cerin lagoon. Recent limulids, such as L. polyphemus, spend most of their life in the subtidal zone, except of annual spawning migrations (Botton and Ropes 1987). Females lay their eggs in shallow nests on the beach and some days after hatching, juveniles have a benthic life in the intertidal zone for two years before moving into deeper environments (Rudloe 1981; Shuster and 1982; Sekiguri 1988; Brockmann 1990, 2003). Considering the Cerin environment, the occurrence of living adults in shallow waters and in a typical marginal marine environment could point to a spawning behaviour on the sandy beaches surrounding the lagoon. However, concrete evidence to support this spawning hypothesis is missing. Traces of juvenile limulids, which show similarities with Nereites (Martin and Rindsberg, 2007), are absent in the Lithographic Limestones of Cerin. Nevertheless, it is interesting to note that the surrounding area of 
Fig. 9 Data used for the estimation of the trackmaker length. a Correspondence between the width of the prosoma and the external width of Kouphichnium. I width of the prosoma; $W$ external width of the trackway (after Malz 1964). b Proportions of the living Limulus polyphemus. $L$ total length; $l$ width of the prosoma (after Pechenik 2000)
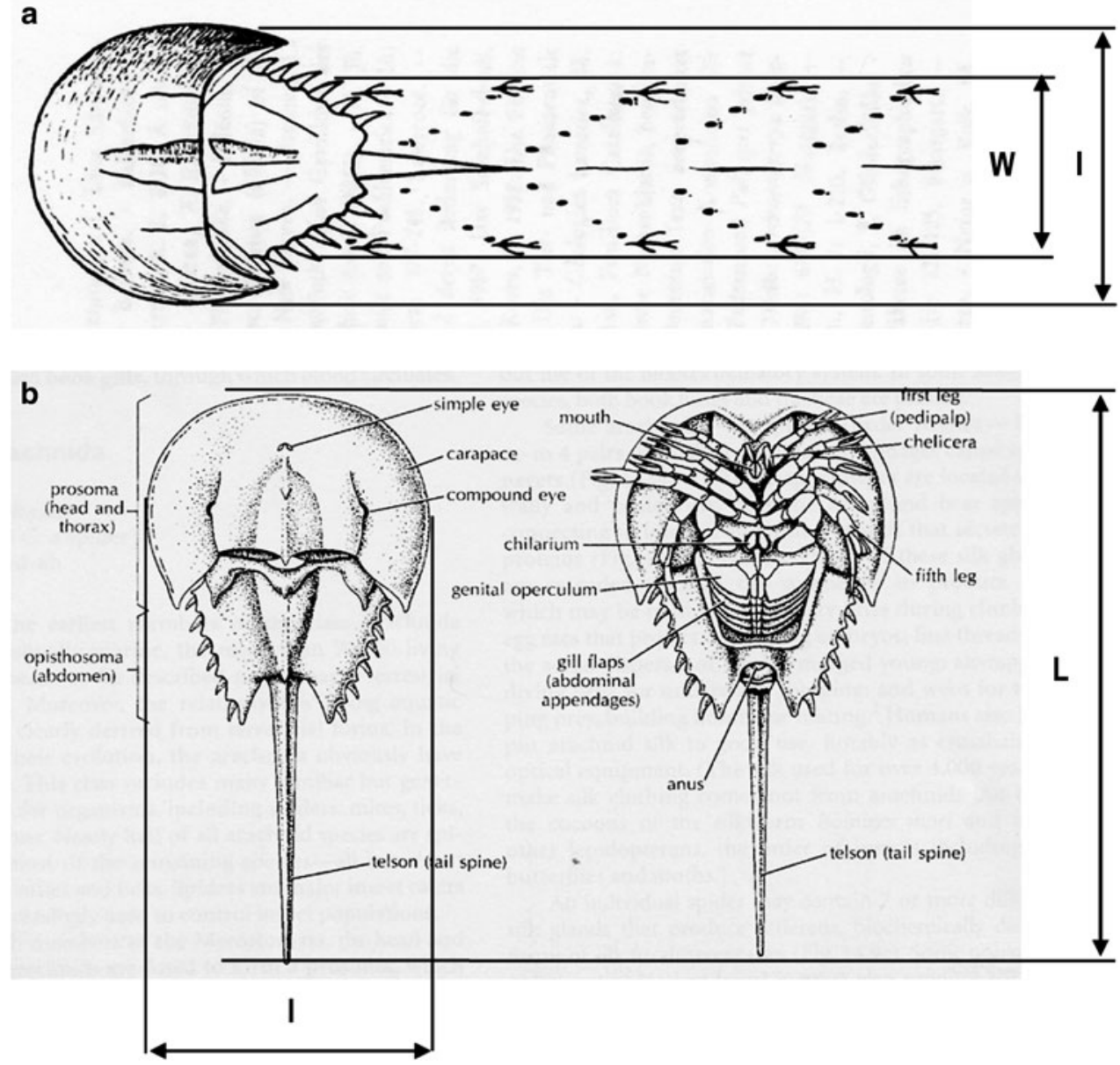

the Cerin lagoon has been considered as a possible nesting area for sea turtles (Gaillard et al. 2003). The co-occurrence of limulids and sea turtles in the surroundings of the lagoon of Cerin is also interesting because limulids were probably a prey of sea turtles. Recent data show that limulids play an important ecological role in the food web of sea turtles. For example loggerhead turtles (Caretta caretta) feed extensively on horseshoe crabs (Lutcavage and Musick 1985; Keinath 2003). Following these considerations, limulids and sea-turtles were possibly active animals within the Cerin ecosystem.

\section{Conclusions}

The studied trackway was made by a very large marine limulid about $38 \mathrm{~cm}$ wide and $80 \mathrm{~cm}$ long, when compared to the proportions of the modern Limulus polyphemus. Most likely, the trackway indicates a normal but rapid locomotion of the trackmaker on the sea floor.
The main characteristics of the trackway are: straightness; well-marked tetradactyl or quadrigid imprints of external legs (VI) named pushers; discrete and straight intermediate imprints (legs III-V); absence of leg II imprint (pedipalp); low angle of leg traces to the mid-line; absence of median imprint (telson); great repeat distance (stride).

This trackway illustrates walking behaviour quite different from crawling, dying or ploughing activities commonly indicated by other fossil limulid trackways. The main characteristics of these different trackways can easily be differentiated.

The behaviour documented by the studied trackway indicates that normal marine conditions occasionally occurred in the Cerin lagoon, at least during short time intervals. This could indicate the occurrence of short-term connections between the restricted lagoon and the open sea. This trackway associated with two fossil limulids at the base of the Lithographic Limestones Unit of Cerin testifies a decrease of the marine influence in the Cerin lagoon, as previously noted using other sedimentological, paleontological, and palichnological evidence. 


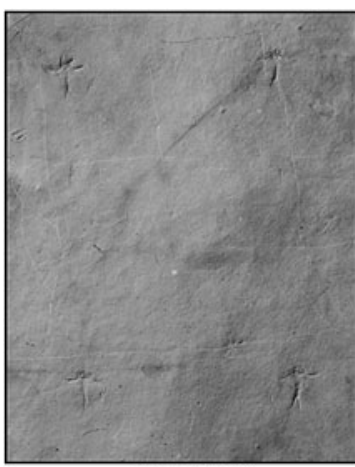

WALKING

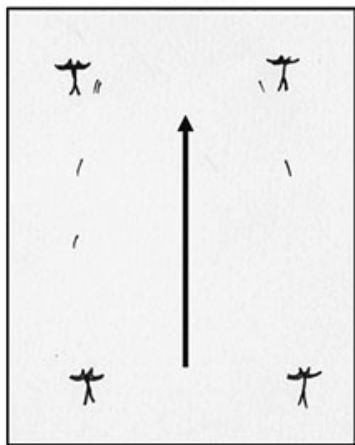

Legs only

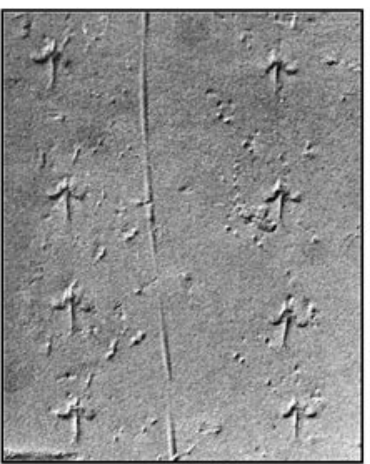

CRAWLING

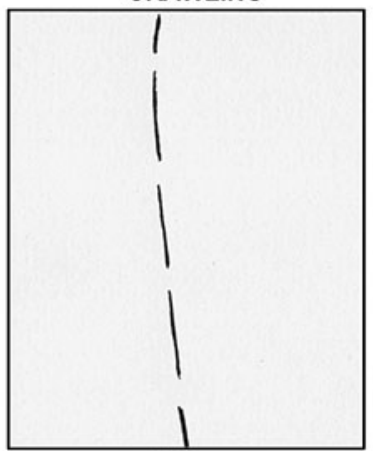

+ Telson

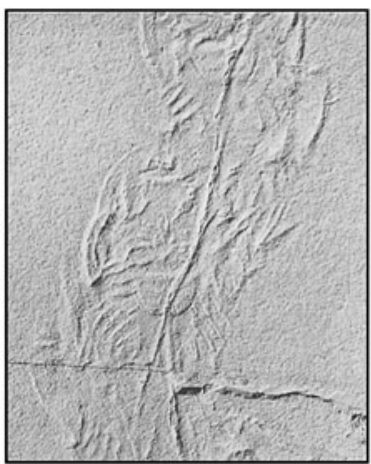

DYING

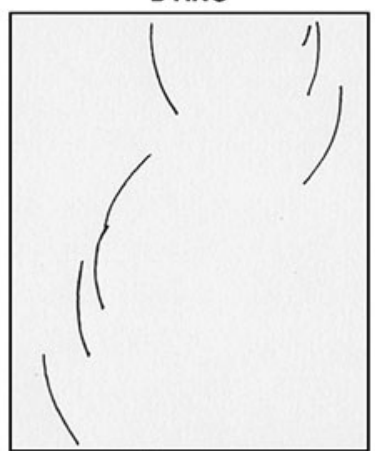

+ Prosoma

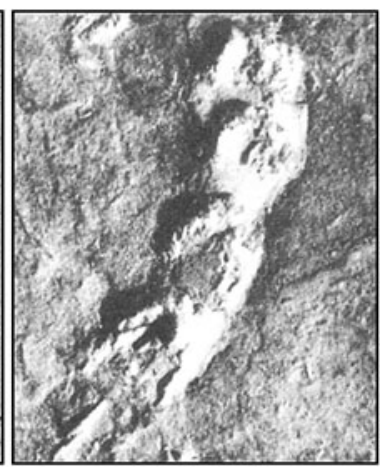

PLOUGHING

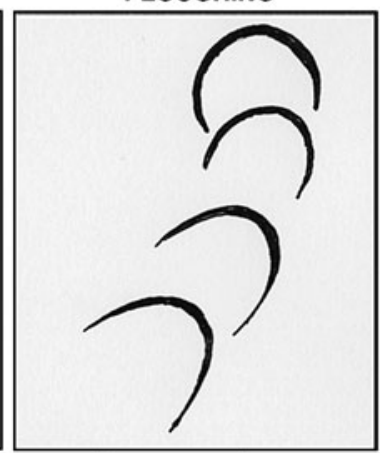

Prosoma deep

Fig. 10 Different fossil limulid trackways and their relation between morphology and behaviour. Walking: this work; crawling: after Kolb (1963); dying after Barthel et al. (1990); ploughing after Hardy (1970)

Table 9 Characterization of trackways corresponding to the four main locomotion styles of limulids

\begin{tabular}{|c|c|c|c|c|}
\hline \multicolumn{5}{|l|}{ Behaviour } \\
\hline Locomotion style & WALKING & CRAWLING & DYING & PLOUGHING \\
\hline Locomotion rate & High & Medium & Low & Very low \\
\hline \multicolumn{5}{|l|}{ Resulting traces } \\
\hline Trackway & Straight & Straight & Sinuous & Sinuous \\
\hline Prosoma imprints & Absent & Absent & Slight & Deep \\
\hline Telson imprints & Absent & Continuous & Interrupted & Interrupted \\
\hline Pushers imprints & Well marked & Well marked & Slight & Absent \\
\hline Walking legs imprints & Short & Short & Long & Absent \\
\hline Series length & High & Medium & Low & $\mathrm{X}$ \\
\hline Repeat distance & High & Medium & Low & $\mathrm{X}$ \\
\hline Imprint spacing & High & Medium & Low & $\mathrm{X}$ \\
\hline Angle to mid-line & Low & Medium & High & $\mathrm{X}$ \\
\hline
\end{tabular}

The occurrence of adult limulids in a typical marginal marine environment could indicate spawning behaviour, but compelling arguments for this hypothesis are still lacking.

Acknowledgments This work was supported by the CNRS (UMR 5125 "Paléoenvironnements et Paléobiosphère"). Financial support and equipment were also provided by the Conseil Général de l'Ain and the Museum of Natural History of Lyon. The author is very grateful to the scientific team of the Cerin program (Paul Bernier,
Jean-Paul Bourseau, George Barale, Eric Buffetaut, Jean-Claude Gall and Sylvie Wenz) for discussions in the field, Günter Viohl (Jura Museum, Eichstätt) for documentation about the Solnhofen Lagerstätte, Martin Daigneault for data on living limulids, Jean-Simon Pages (Réserve Naturelle Géologique de Haute Provence) for access to aquariums with living limulids and to the journal reviewers Martin Lockley and Andreas Wetzel for constructive suggestions, which helped to improve the manuscript. The author is also very grateful to Jean-Claude Reniaud and Gérard Sirven for logistic assistance, Arlette Armand for drawing assistance, Noël Podevigne for photographic printing and Abel Prieur for collection management. 


\section{References}

Abel, O. (1926). Amerikafahrt: Eindrücke Beobachtungen und Studien eines Naturforschers auf einer Reise nach Nordamerika und Westindien (462 p.). Jena: Gustav Fisher.

Abel, O. (1935). Vorzeitliche Lebensspuren (644 p.). Jena: Gustav Fischer.

Babcock, L. E., Merriam, D. F., \& West, R. R. (2000). Paleolimulus, an early limuline (Xiphosurida), from Pennsylvanian-Permian Lagerstätten of Kansas and taphonomic comparison with modern Limulus. Lethaia, 33, 129-141.

Bandel, K. (1967). Isopod and limulid marks and trails in Tonganoxie sandstone (Upper Pennsylvanian) of Kansas. Paleontological Contributions (Vol. 19, 10 pp.). The University of Kansas.

Barale, G., Bernier, P., Bourseau, J. P., Buffetaut, E., Gaillard, C., Gall, J. C., et al. (1985). Cerin, une lagune tropicale au temps des dinosaures (136 p.). Lyon: Centre National de la Recherche Scientifique \& Muséum d'Histoire Naturelle de Lyon.

Barthel, K. W. (1974). Limulus: A living fossil Horseshoe crabs aid interpretation of an Upper Jurassic environment (Solnhofen). Naturwissenschaften, 61, 428-433.

Barthel, K. W. (1978). Solnhofen-Ein Blick in die Erdgeschichte (393 p.). Thun: Ott Verlag.

Barthel, K. W., Swinburne, N. H. M., \& Conway Morris, S. (1990). Solnhofen A study in Mesozoic Palaeontology (236 p.). Cambridge: Cambridge University Press.

Bernier, P. (1984). Les formations carbonatées du Kimméridgien et du Portlandien dans le Jura méridional (Stratigraphie, micropaléontologie, sédimentologie). Documents des Laboratoires de Géologie de Lyon, 92, 1-731.

Bernier, P. (1994). For a reinstatement of "lithographic" a precise word to define a precise limestone. Geobios Special Issue, 16, 307-311.

Bernier, P., \& Gaillard, C. (1990). Les Calcaires lithographiques de Cerin (Jura méridional, France). 3e Symposium International sur les Céphalopodes actuels et fossiles, Lyon, livret-guide, Excursion A, 1-30.

Bernier, P., Barale, G., Bourseau, J. P., Buffetaut, E., Demathieu, G., Gaillard, C., et al. (1982). Traces nouvelles de locomotion de Chélonien et figures sédimentaires associées dans les Calcaires lithographiques de Cerin (Kimméridgien supérieur, Ain, France). Geobios, 14, 447-467.

Bernier, P., Barale, G., Bourseau, J. P., Buffetaut, E., Demathieu, G., Gaillard, C., et al. (1984). Découverte de pistes de Dinosaures sauteurs dans les calcaires lithographiques de Cerin (Kimméridgien supérieur, Ain, France) Implications paléoécologiques. Geobios Special Issue, 8, 177-185.

Bernier, P., Barale, G., Bourseau, J. P., Buffetaut, E., Gaillard, C., Gall, J. C., \& Wenz, S. (1991a). The paleoecological excavations at Cerin (Southern french Jura Mountains). Results and Interpretation. Geobios Special Issue 16 (supplément 2), 1-35.

Bernier, P., Gaillard, C., Gall, J. C., Barale, G., Bourseau, J. P., Buffetaut, E., et al. (1991b). Morphogenetic impact of microbial mats on surface structures of lithographic limestones (Cerin area, Kimmeridgian, France). Sedimentology, 38, 127-136.

Bernier, P., Barale, G., Bourseau, J. P., Buffetaut, E., Gaillard, C., Gall, J. C., \& Wenz, S. (1991b). Les algues Dasycladales des Calcaires Lithographiques de Cerin. Signification environnementale et taphonomique. International Round-Table 'Lithographic Limestones', Abstracts. Geobios Special Issue 16 (supplément 1), 8 p.

Bernier, P., Gaillard, C., Barale, G., Bourseau, J. P., Buffetaut, E., Gall, J. C., et al. (1994). The underlying substrate of the Cerin Lithographic Limestone. Geobios Special Issue, 16, 13-24.
Böhm, H. (1905). Über Limulus decheni Zincken. Jahrbuch der Kaiserlich-Königlichen Preussischen Geologischen Landesanstalt und Bergakademie zu Berlin, 26, 240-245.

Botton, M. L. (1984). Diet and food preferences of the adult horseshoe crab, Limulus polyphemus, in the Delaware Bay, New Jersey, USA. Marine Biology, 81, 199-207.

Botton, M. L., Shuster, C. N. Jr., \& Keinath, J. A. (2003). Horseshoe crabs in a food web: Who eats whom? In: C. H. Shuster, Jr., R. B. Barlow, \& Brockmann, H. J (Eds.), The American horseshoe crab (pp. 133-153). Cambridge: Harvard University Press.

Botton, M. L., \& Ropes, J. W. (1987). The horseshoe crab, Limulus polyphemus, fishery and resource in the United States. Marine Fisheries Review, 49, 57-61.

Botton, M. L., \& Ropes, J. W. (1989). Feeding ecology of horseshoe crabs on the continental shelf, New Jersey to North Carolina. Bulletin of Marine Science, 45, 637-647.

Bourseau, J. P., Buffetaut, E., Barale, G., Bernier, P., Gaillard, C., Gall, J. C., et al. (1984). La carrière des calcaires lithographiques de Cerin (Ain, commune de Marchamp) Vie et extinction d'une exploitation communale sur un gisement paléontologique célèbre. Nouvelles Archives du Muséum d'Histoire Naturelle de Lyon, 22, 21-30.

Bourseau, J. P., Hess, H., Barale, G., Bernier, P., Buffetaut, E., Gaillard, C., Gall, J. C., \& Wenz, S. (1991). Découverte d'ophiures dans les calcaires lithographiques de Cerin (Kimméridgien supérieur, Ain, France). Systématique et implications taphonomiques. Comptes Rendus de l'Académie des Sciences, Paris 312, Série II, 793-799.

Bourseau, J. P., Bernier, P., Barale, G., Buffetaut, E., Gaillard, C., Gall, J. C., et al. (1994). Taphonomie des Echinides du gisement de Cerin (Kimméridgien supérieur, Jura méridional, France) Implications environnementales. Geobios Special Issue, 16, $37-47$.

Braddy, S. J. (2001). Trackways-Arthropod locomotion. In: D. E. G. Briggs, \& P. R. Crowther (Eds), Palaeobiology II (pp. 389-393). Blackwell: Oxford.

Breton, G., Bourseau, J. P., Bernier, P., Barale, G., Buffetaut, E., Gaillard, C., et al. (1994). Les Astérides (Asteroidea, Echinodermata) des Calcaires Lithographiques kimméridgiens de Cerin (Ain, France). Geobios Special Issue, 16, 49-60.

Brockmann, H. J. (1990). Mating behaviour of horseshoe crabs, Limulus polyphemus. Behaviour, 114, 206-220.

Brockmann, H. J. (2003). Nesting behaviour: A shoreline phenomenon. In: C. H. Shuster, Jr., R. B. Barlow, \& H. J. Brockmann (Eds.), The American horseshoe crab (pp. 33-47): Cambridge: Harvard University Press.

Buatois, L. A., Mangano, M. G., Maples, C. G., \& Lanier, W. P. (1998). Ichnology of an Upper Carboniferous fluvio-estuarine paleovalley: The Tonganoxie Sandstone, Buildex quarry, Eastern Kansas, USA. Journal of Paleontology, 72, 152-180.

Buffetaut, E., Bernier, P., Barale, G., Bourseau, J. P., Gaillard, C., Gall, J. C., et al. (1990). A new pterosaur bone from the Kimmeridgian lithographic Limestones of Cerin (France). Neues Jahrbuch für Geologie und Paläontologie. Monatshefte, 1990(6), $321-328$.

Caster, K. E. (1938). A restudy of the tracks of Paramphibius. Journal of Paleontology, 12, 3-60.

Caster, K. E. (1939). Were Micrichnus scotti ABEL and Artiocactylus sinclairi ABEL of the Newark series (Triassic) made by vertebrates or limuloids? American Journal of Science, 237, 786-797.

Caster, K. E. (1940). Die sogenannten "Wirbeltierspuren" und die Limulus-Fährten der Solnhofener Plattenkalke. Paläontologische Zeitschrift, 22, 12-29. 
Caster, K. E. (1944). Limuloid trails from the Upper Triassic (Chinle) of the petrified forest national monument, Arizona. American Journal of Science, 242, 74-84.

Chisholm, J. I. (1983). Xiphosurid traces, Kouphichnium aff. variabilis (Linck), from the Namurian Upper Haslingden Flags of Whitworth, Lancashire. Report of the Institute of Geological Sciences, 83(10), 37-44.

Conti, M.A., Leonardi, G., Manni, R., \& Venturini C. (1991). Limuloid tracks into the Meledis Fm. (Upper Carboniferous, Kasimovian) of the Carnic Alps. Giornale di Geologia ser, $3 a(53), 151-159$.

Desmarest, A. G. (1822). Les Crustacés proprement dits. In: A. Brongniart , A.G. Desmarest (Eds.), Histoire naturelle des Crustacés Fossiles (154 p.). Paris: F.G. Levrault.

Eagar, R. M. C., Baines, J. G., Collinson, J. D., Hardy, P. G., Okolo, S. A., \& Pollard, J. E. (1985). Trace fossil assemblages and their occurrence in Silesian (mid-Carboniferous) deltaic sediments of the Central Pennine Basin, England. In: H. A. Curran (Ed.), Biogenic structures: Their use in interpreting depositional environments. Society of Economic Paleontologists and Mineralogists (Vol. 35, 99-149 pp.). Special Publication, Tulsa.

Eldredge, N. (1970). Observations on burrowing behavior in Limulus polyphemus (Chelicerata, Merostomata), with implications on the functional anatomy of trilobites, American Museum of Natural history (17 p.). New York: American Museum Novitates.

Enay, R., Bernier, P., Barale, G., Bourseau, J. P., Buffetaut, E., Gaillard, C., et al. (1994). Les ammonites des Calcaires Lihographiques de Cerin (Ain, France): Stratigraphie et taphonomie. Geobios Special Issue, 16, 25-36.

Fischer, W. A. (1978). The habitat of the early vertebrates: Trace and body fossil evidence from the Harding Formation (Middle Ordovician), Colorado. Mountain Geologists, 15, 1-26.

Fischer, D. C. (1984). The Xiphosurida: Archetypes of bradytely? In: E. Eldredge, \& S. M. Stanley (Eds.), Living fossils (196-213 pp.), Berlin: Springer.

Frickhinger, K. A. (1994). The fossils of Solnhofen (336 p.). Korb: Goldschneck-Verlag.

Gaillard, C., Bernier, P., \& Gruet, Y. (1994a). Le lagon d'Aldabra (Seychelles, Océan Indien), un modèle pour le paléoenvironnement de Cerin (Kimméridgien supérieur, Jura méridinal, France). Geobios, Special Issue, 16, 331-348.

Gaillard, C., Bernier, P., Gall, J. C., Gruet, Y., Barale, G., Bourseau, J. P., et al. (1994b). Ichnofabric from the Upper Jurassic lithographic limestone of Cerin, Southeast France. Palaeontology, 37, 284-304.

Gaillard, C., Bernier, P., Barale, G., Bourseau, J. P., de Broin, F., Buffetaut, E., et al. (2003). An Upper Jurassic giant turtle revealed by its trackways. Lethaia, 36, 315-322.

Gaillard, C., Goy, J., Bernier, P., Bourseau, J. P., Gall, J. C., Barale, G., et al. (2006). New jellyfish taxa from the Upper Jurassic lithographic limestones of Cerin (France)-taphonomy and ecology. Palaeontology, 49, 1287-1302.

Gall, J. C., Bernier, P., Gaillard, C., Barale, G., Bourseau, J. P., Buffetaut, E., et al. (1985). Influence du développement d'un voile algaire sur la sédimentation et la taphonomie des calcaires lithographiques. Exemple du gisement de Cerin (Kimméridgien supérieur, Jura méridional français). Comptes Rendus de l'Académie des Sciences, Paris, 301, 547-552.

Gall, J. C., Bernier, P., Barale, G., Bourseau, J. P., Buffetaut, E., Gaillard, C., et al. (1996). Découverte de limules dans les calcaires Lithographiques de Cerin (Kimméridgien, france). Archaeopteryx, 14, 75-81.

Goldring, R., \& Seilacher, A. (1971). Limulid undertracks and their sedimentological implications. Neues Jahrbuch für Geologie und Paläontologie, Abhandlungen, 137, 422-442.
Groiss, Von J. T. (1975). Eine Spurenplatte mit Kouphichnium (Mesolimulus) walchi (Desmarest, 1822) aus Solnhofen. Geologische Blätter für Nordost-Bayern, 25, 80-95.

Häntzschel, W. (1975). Trace fossils and problematica. In: C. Teichert (Ed.), Treatise on invertebrate paleontology, part W., Miscellanea, (2nd ed., W1-W269). Boulder: Geological Society of America and University of Kansas Press.

Hardy, P. G. (1970). New Xiphosurid trails from the Upper Carboniferous of Northern England. Palaeontology, 13, 188190.

Harris, J. D., \& Lacovara, K. J. (2004). Enigmatic fossil footprints from the Sundance Formation (Upper Jurassic) of Bighorn Canyon national recreation area, Wyoming. Ichnos, 11, 151166.

Haubold, H. (1971). Ichnia Amphibiorum et Reptiliorum fossilium. In: O. Kuhn (Ed.), Encyclopedia of Paleoherpetology (Vol. 18, 124 p.). Stuttgart: Gustav Fischer.

Hauschke, N., \& Wilde, V. (1991). Zur Verbreitung und Ökologie mesozoischer Limuliden. Neues Jahrbuch für Geologie und Paläontologie, Abhandlungen, 183, 391-411.

Jaekel, O. (1929). Die Spur eines neuen Urvogels (Protornis bavarica) und deren Bedeutung für die Urgeschichte der Vögel. Paläontologische Zeitschrift, 11, 201-238.

Keinath, J. A. (2003). Predation of horseshoe crabs by loggerhead sea turtles. In: C. H. Shuster, Jr., R. B. Barlow, \& H. J. Brockmann, (Eds.), The American horseshoe crab (pp. 152-153), Cambridge: Harvard University Press.

Kolb, A. (1963). Riesige Limulus-Fährte aus den lithographischen Schiefern bei Pfalzpaint. Geologische Blätter für NordostBayern, 13, 73-78.

Leonardi, G. (1987). Glossary and manual of tetrapod footprint palaeoichnology (p. 117). Brasília: Publicação do Departemento Nacional da Produção Mineral Brasil.

Linck, O. (1943). Die Buntsandstein-Kleinfährten von Nagold. (Limuludichnulus nagoldensis n. g. n. sp. Merostomichnites triassicus n. sp.). Neues Jahrbuch für Mineralogie, Geologie und Paläontologie, Monatshefte, B, 9-27.

Linck, O. (1949). Lebens-Spuren aus dem Schilfsandstein (Mittl. Keuper km 2) NW-Württemberg und ihre Bedeutung für die Bildungsgeschichte der Stufe. Jahreshefte des Vereins für Vaterländische Naturkunde in Württemberg, 97(101), 1-100.

Lockley, M. G., \& Matsukawa, M. (2009). A review of vertebrate track distributions in East and Southeast Asia. Journal of the Paleontological Society of Korea, 25, 17-42.

Lutcavage, M., \& Musick, J. A. (1985). Aspects of the biology of sea turtles in Virginia. Copeia, 1985, 449-456.

Malz, H. (1964). Kouphichnium walchi, die Geschichte einer Fährte und ihres Tieres. Natur und Museum, 94, 81-97.

Martin, A. J., \& Rindsberg, A. K. (2007). Arthropod tracemakers of Nereites? Neoichnological observations of juvenile limulids and their paleoichnological applications. In: W. Miller III (Ed.), Trace fossils, concepts, problems, prospects (pp. 478-491), Amsterdam: Elsevier.

Martinsson, A. (1970) Toponomy of trace fossils. In: T. P. Crimes, \& J. C. Harper, (Eds.), Trace fossils, Geological Journal, Special Issue 3 (pp. 323-330), Liverpool: Seel House Press.

Miller, M. F. (1982). Limulicubichnus: A new ichnogenus of limulid resting traces. Journal of Paleontology, 56, 429-433.

Moore, R. A., McKenzie, S. C., \& Lieberman, B. S. (2007). A Carboniferous Synziphosurine (Xiphosura) from the Bear Gulch Limestone, Montana, USA. Palaeontology, 50, 10131019.

Nielsen, E. (1949). On some trails from the Triassic beds of East Greenland. Muséum de mineralogy et de géologie de l'Université de Copenhague, Communications paléontologiques 70 , $44 \mathrm{pp}$. 
Nopsca, F. (1923). Die Familien der Reptilien. Fortschritte der Geologie und Paläontlogie, 2, 1-210.

Oishi, H., Matsukuma, A., \& Aihara, A. (1993). Limulid trace fossils from the Oligocene of Takeo, Saga Prefecture, Japan. Science reprints, Department Earth and Planetary Science, Kyushu University, 18, 73-84.

Oppel, A. (1862). Über Fährten im lithographischen Schiefer (Ichnites lithographicus). Paläontologische Mitteilungen aus dem Museum des Königlichen Bayerischen Staates, Stuttgart, 1, 121-125.

Packard, A. S. (1900). On supposed merostomatous and other Paleozoic Arthropod trails with notes on those of Limulus. Proceedings of the American Academy of Arts and Sciences, 36, 64-71.

Pechenik, J. A. (2000). Biology of the Invertebrates (4th edn, 578 pp.). New Work: McGraw-Hill

Pickett, J. W. (1984). A new freshwater limuloid from the Middle Triassic of New South Wales. Palaeontology, 27, 609-621.

Richter, R., \& Richter, E. (1929). Weinbergina opitzi, n g., n. sp., ein Schwertträger (Merost, Xiphos) aus dem Devon (Rheinland). Senckenbergiana, 11, 193-209.

Riek, E. F., \& Gill, E. D. (1971). A new Xiphosuran genus from Lower Cretaceous freshwater sediments at Koonwarra, Victoria, Australia. Palaeontology, 14, 206-210.

Romano, M., \& Whyte, M. A. (1987). A limulid trace fossil from the Scarborough formation (Jurassic) of Yorkshire: Its occurrence, taxonomy and interpretation. Proceedings of the Yorkshire Geological Society, 46, 85-95.

Romano, M., \& Whyte, M. A. (1990). Selenichnites, a new name for the ichnogenus Selenichnus Romano \& Whyte, 1987. Proceedings of the Yorkshire Geological Society, 48, 221.

Romano, M., \& Whyte, M. A. (2003). The first record of Xiphosurid (Arthropod) trackways from the saltwick formation, Middle Jurassic of the Cleveland basin, Yorkshire. Palaeontology, 46, 257-269.

Rudkin, D. M., Young, G. A., \& Nowlan, G. S. (2008). The oldest horseshoe crab: A new xiphosurid from Late Ordovician konservat-lagerstätten deposits, Manitoba, Canada. Palaeontology, 51, 1-9.

Rudloe, A. (1981). Aspects of the biology of juvenile horseshoe crabs, Limulus polyphemus. Bulletin of Marine Science, 31, 125-133.

Schweigert, G. (1998). Die Spurenfauna des Nusplinger Plattenkalks (Oberjura, Schwäbische Alb). Stuttgarter Beiträge zur Naturkunde aus dem Staatlichen Museum für Naturkunde in Stuttgart $B, 262,1-47$.

Schweigert, G., \& Dietl, G. (2002). Miscellanea aus dem Nusplinger Plattenkalk (Ober-Kimmeridgium, Schwäbische Alb). Jahresberichte und Mitteilungen des Oberrheinischen Geologischen Vereins $N F, 84,323-331$

Seilacher, A. (1959). Vom Leben der Trilobiten. Naturwissenschaften, 46, 389-393.

Seilacher, A. (2007). Trace fossil analysis (226 p.), New York: Springer.

Seilacher, A., Reif, W. E., \& Westphal, F. (1985). Sedimentological, ecological and temporal patterns of fossil Lagerstätten. Philosophical Transactions of the Royal Society of London B, 311, 5-23.
Sekiguri, K. (1988). Biology of horseshoe crabs (p. 428). Tokyo: Science House Co.

Shuster, C. N. Jr. (1982). A pictorial review of the natural history and ecology of the horseshoe crab Limulus polyphemus, with reference to other Limulidae. In.: J. Bonaventura , C. Bonaventura, \& S. Tesh, (Eds.), Physiology and biology of horseshoe crabs. Studies on normal and environmentally stressed animals (1-52 pp.). New York: Alan R. Liss, Inc.

Shuster, C. N. Jr., Barlow, R. B., \& Brockmann, H. J. (2003). The American horseshoe crab (427 p.). Cambridge: Harvard University Press.

Siveter, D. J., \& Selden, P. A. (1987). A new, giant xiphosurid from the lower Namurian of Weardale, County Durham. Proceedings of the Yorkshire Geological Society, 46, 153-168.

Størmer, L. (1952). Phylogeny and taxonomy of fossil horseshoe crabs. Journal of Paleontology, 26, 630-639.

Størmer, L., (1955). Merostomata. In: R. C. Moore, (Ed.), Treatise on invertebrate Paleontology P, Arthropoda 2 (pp. 4-41).

Trewin, N. H. (1994). A draft system for the identification and description of arthropod trackways. Palaeontology, 37, 811-823.

Van Straelen, M.V. (1924). Les Crustacés Décapodes du Portlandien de Cerin-Marchampt (Ain). Comptes Rendus des Séances de l'Académie des Sciences, t. 175, séance du 11/12/1922, 3 p.

Via Boada, L., \& Villalta, J.F. de (1966). Heterolimulus gadeai, nov. gen., nov. sp., représentant d'une nouvelle famille de Limulacés dans le Trias d'Espagne. Compte Rendu Sommaire des Séances de la Société Géologique de France, 2, 57-59.

Vijayakumar, R., Das, S., Chatterji, A., \& Parulekar, A. H. (2000). Morphometric characteristics in the horseshoe crab Tachypleus gigas (Arthropoda: Merostomata). Indian Journal of Marine Sciences, 29, 333-335.

Viohl, G. (1998). Die Solnhofener Plattenkalke-Entsthehung und Lebensräume. Archaeopteryx, 16, 37-68.

Vosatka, E. D. (1970). Observations on the swimming, righting, and burrowing movements of young horseshoe crabs, Limulus polyphemus. The Ohio Journal of Science, 70, 276-283.

Walther, J. (1904). Die Fauna der Solnhofener Plattenkalke. Bionomisch betrachtet. Denkschriften der Medizinisch-Naturwissenschaftlichen Gesellschaft zu Jena (Vol. II, 135-214 pp.), Jena: Gustav Fischer.

Wang, G. (1993). Xiphosurid trace fossils from the Westbury Formation (Rhaetian) of Southwest Britain. Palaeontology, 36, 111-122.

Wenz, S., Bernier, P., Barale, G., Bourseau, J. P., Buffetaut, E., Gaillard, C., et al. (1994). L'ichthyofaune des Calcaires Lithographiques du Kimméridgien supérieur de Cerin (Ain, France). Geobios Special Issue, 16, 61-70.

Willard, B. (1935). Chemung tracks and trails from Pennsylvania. Journal of Paleontology, 9, 43-56.

Zincken, C. (1862). Limulus decheni aus dem Braunkohlen-Sandstein bei Teuchern. Zeitschrift für die gesamte Naturwissenschaft, 19, 329-331. 